\title{
Electronic Customer Relationship Management (E-CRM) Application as Efforts to Increase Customer Retention of Micro Small and Medium Enterprises (MSMEs) in Banten Indonesia
}

\author{
Vidila Rosalina \\ Faculty of Information Technology \\ - Universitas Serang Raya \\ Jl. Raya Serang-Cilegon Km.5 \\ Taman Kopassus Serang Banten \\ Indonesia
}

\author{
Hamdan \\ Faculty of Economy - Universitas \\ Serang Raya \\ Jl. Raya Serang-Cilegon Km.5 \\ Taman Kopassus Serang Banten \\ Indonesia
}

\author{
Agung Triayudi \\ Departement of Informatic- \\ Universitas Nasional \\ Jakarta Indonesia
}

\begin{abstract}
Currently, the Micro, Small and Medium Enterprises (MSMEs) in Banten Indonesia mostly still manage their customers in conventional ways, the touch of information technology has not been done much. One approach to modern business is to pay attention to the factors of good relationships with customers, not only before the transaction, but also after the transaction. The Information Technology System used to manage customer relationships with the aim of increasing customer retention is called Customer Relationship Management (CRM). The existing CRM software is more oriented to large companies that are already established, so that it will cause some discrepancies when applied in MSMEs. This study tries to develop E-CRM software that is tailored to the business needs of MSMEs in Banten by using a local approach to facilitate users in their use. This feature in the ECRM will help MSMEs in implementing customer relationship management so that they can increase their competitiveness with other companies in maintaining the business they are running and as a means to obtain a wider new market. The approach used by local policy is through observations made on MSMEs in the Banten region. The application developed in this paper is based on 9 characteristics of the Banten MSMEs produced in previous studies [1] and the E-CRM UMKM blue print model that has been published in international seminars [2]. This application development used the stages that exist in the waterfall model method, namely planning, analysis, design, and implementation. The results of the E-CRM UMKM Application are expected to increase customer retention and build global marketing for MSMEs in the Banten region of Indonesia.
\end{abstract}

\section{Keywords}

Customer relationship management; electronic customer relationship management; electronic customer relationship management application; micro and medium enterprises

\section{INTRODUCTION}

Micro, Small and Medium Enterprises (MSMEs) are one of the driving sectors of the Indonesian economy that can survive in the face of intense global business competition like today. The number of workers in the MSME sector in early 2012 was almost 80 million people, this requires more attention to encourage MSME managers to improve their business empowerment. There are several factors that influence the performance of MSMEs in maintaining their business, including financing, human resources, market share, business climate, supporting facilities and infrastructure, and information access [3].

There are several obstacles that can hinder the performance of MSMEs in maintaining their business. Peni Sawitri, et al. (2012) said that the obstacles that are often faced by MSMEs namely having difficulty in marketing their products and maintaining existing markets, as well as constraints to innovation and financial management that have not been optimal have caused MSME business actors to not last long. To be able to survive in maintaining its business, MSMEs are required to be able to start implementing various strategies in their business development efforts. Every MSME business actor is not only required to be able to create unique products but also can market products. Without a good marketing strategy, it can be ensured that the empowerment of MSMEs cannot grow rapidly [4].

Marketing is growing rapidly and understanding consumer behavior is one strategy in the success of marketing products [5]. The obstacle that is often faced by most MSMEs is the difficulty of marketing their products and maintaining existing markets in addition to several other obstacles such as not optimal innovation, household finance mixed with traditional finance and industrial management. Understanding and maintaining customers is one of the strategies in the success of the company. This often becomes a major obstacle to MSMEs in the midst of increasingly fierce competition. MSMEs need to maintain good relationships with customers and increase their loyalty through knowledge and fulfillment of customer needs quickly and precisely. Customer Relationship Management (CRM) as an information technology application will be able to overcome this problem because CRM aims to manage customer relationships. CRM can help MSMEs develop new products based on complete knowledge of customer desires, market dynamics and competitors. Thus in the context of MSMEs, they will get a better understanding of their customers and their needs on the combination of data warehouse, data bank and help desk or call center.

This research was conducted to develop applications or Electronic Customer Relationship Management (E-CRM) software for MSMEs in the Banten region of Indonesia. CRM applications are now widely distributed in the market, mostly made by American and European companies that have already 
implemented CRM in their companies. AMR Research reports several CRM software providers such as Siebel Systems, Microsoft, Clarify (Nortel Networks), PeopleSoft and Oracle as market leaders. Meanwhile, CRM professional service companies which are market leaders such as Accenture, Art Technology Group, Cambridge Technology Partners, CSC, Deloitte Consulting, EDS, eLoyalty, Cap Gemini Ernst \& Young, IBM Global Services, KPMG Consulting and Price Waterhouse Coopers. This shows that CRM software providers are mostly foreign companies that might make MSMEs reluctant to use CRM applications into their business ventures, because of the high cost of the application and foreign vendors still lack understanding of unique small and medium business process preparation [6] [11] [12] [13]. This research is motivated by the fact that there are currently no MSMEs in the Banten province of Indonesia that have implemented E-CRM, although many MSMEs have realized the importance of E-CRM and the use of information systems is a necessity that cannot be avoided by any business the foremost position in an industry. The following are MSMEs data in the Banten province (Table 1)

Table 1: MSME Data Based on Business Units in Banten Province

\begin{tabular}{|c|c|c|c|c|}
\hline Business Category & Micro & Small & Medium & Total \\
\hline Mining and excavation & 2.463 & 235 & 19 & 2.717 \\
\hline Processing industry & 79.928 & 9.192 & 787 & 90.907 \\
\hline Electricity, gas and water & 165 & 32 & 86 & 283 \\
\hline Construction & 3.781 & 641 & 221 & 4.643 \\
\hline Retail and trade & 330.959 & 93.852 & 2.685 & 427.496 \\
\hline $\begin{array}{l}\text { Accommodation and provision of } \\
\text { food and drink }\end{array}$ & 127.788 & 24.585 & 452 & 150.825 \\
\hline $\begin{array}{c}\text { Transportation, warehousing and } \\
\text { communication }\end{array}$ & 161.069 & 8.134 & 431 & 169.634 \\
\hline Financial intermediary & 596 & 598 & 462 & 1.656 \\
\hline Real estate, rental business & 46.178 & 5.192 & 572 & 51.942 \\
\hline Educational services & 8.465 & 2.392 & 281 & 11.138 \\
\hline $\begin{array}{c}\text { Health services and social } \\
\text { activities }\end{array}$ & 5.197 & 1.383 & 158 & 6.738 \\
\hline $\begin{array}{l}\text { Community, social culture, } \\
\text { entertainment and other } \\
\text { individuals services }\end{array}$ & 49.912 & 6.995 & 143 & 57.050 \\
\hline $\begin{array}{c}\text { Individual services that serve } \\
\text { households }\end{array}$ & 8.995 & 82 & 12 & 9.089 \\
\hline TOTAL & 823.496 & 153.313 & 7.309 & 984.118 \\
\hline
\end{tabular}

(Source: dinkopukm.bantenprov.go.id)

Meanwhile, based on a survey conducted in 2017 the level of utilization of CRM / E-CRM in MSMEs in Banten province turned out that from sample data of 30 respondents were known $100 \%$ of MSME actors had not utilized and implemented CRM and E-CRM in managing relationships with customers (Figure 1) [7]. 


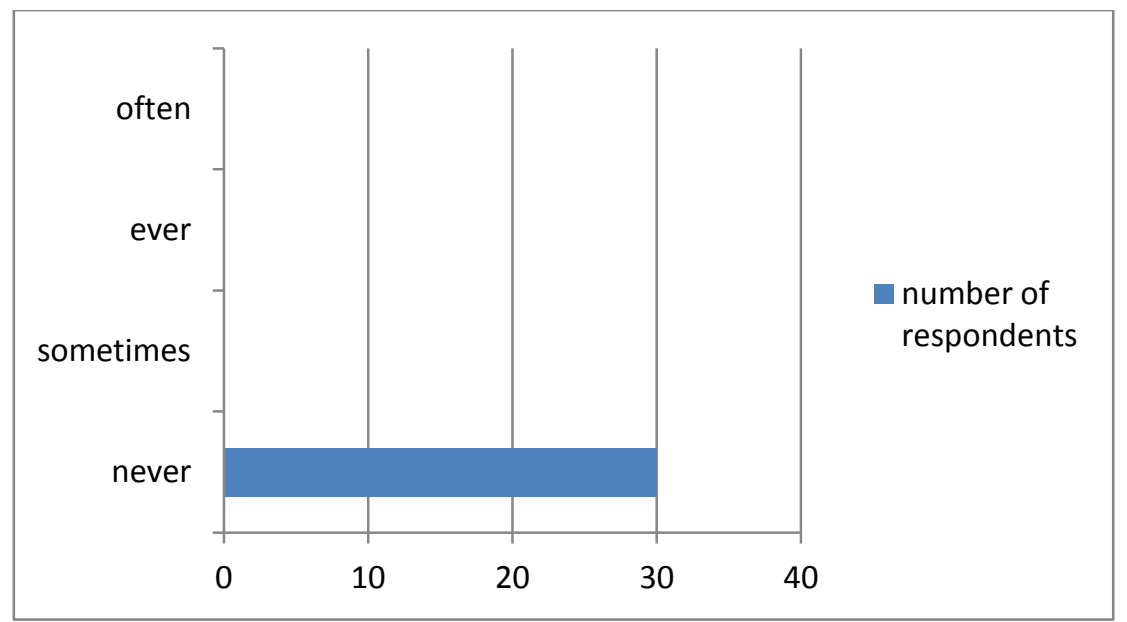

Figure: 1 Utilization Level of CRM/E-CRM in MSMES

This is what motivates this research to be conducted to help MSMEs in their business by designing E-CRM application that is easy and affordable. Thus the formulation of the problem in this study is "How is the software development or Electronic Customer Relationship Management (E-CRM) application in Micro, Small and Medium Enterprises (MSMEs) in Banten province based on the characteristics of the Banten MSMEs using the waterfall method?". The results of the development of the E-CRM UMKM are expected to contribute to development activities in terms of computational techniques. The purpose of this study was to implement technology, especially in the field of ICT to support economic improvement in the Banten region of Indonesia. The features in this E-CRM will help MSMEs in implementing customer relationship management so that they can increase their competitiveness with other companies in maintaining the business they are running and as a means to obtain a wider new market. The development of the E-CRM UMKM application device is through the stages that exist in the waterfall model software development method discovered by Winston W. Royce in 1970, namely planning, analysis, design, and implementation [8]. The results of the E-CRM UMKM application developed in this study are expected to be able to increase customer retention and build global scale marketing in MSMEs in the Banten region of Indonesia.

\section{RESEARCH METHOD}

The following are the steps that have been carried out in the overall research on the development of E-CRM UMKM in Banten province of Indonesia, namely: (1) Observation and Data Collection of MSMEs in Banten Province, (2) Requirement Analysis of E-CRM UMKM in Banten , (3) Requirements for identification systems using the 6 Zachman Framework perspective, namely scope, business model, system model, technology model, component, and working system [14], (4) Produced 10 Characteristics of E-CRM Modeling with Local Wisdom to MSMEs in Banten Province [1] [10], (5) E-CRM UMKM Modeling uses 4 Zachman Framework matrices namely why, how, what, who, (6) CRM Modeling with Unified Model Language (UML) Diagram As Efforts to Increase Retention Customers of MSMEs in Banten Province, (7) Software development based on 9 characteristics of the E-CRM UMKM in Banten by using the Waterfall Model method through the stages: Planning, Analysis, Design, and Implementation, (8) So that E-CRM UMKM Application As Efforts to Increase Customer Retention of MSMEs in Banten Indonesia. 


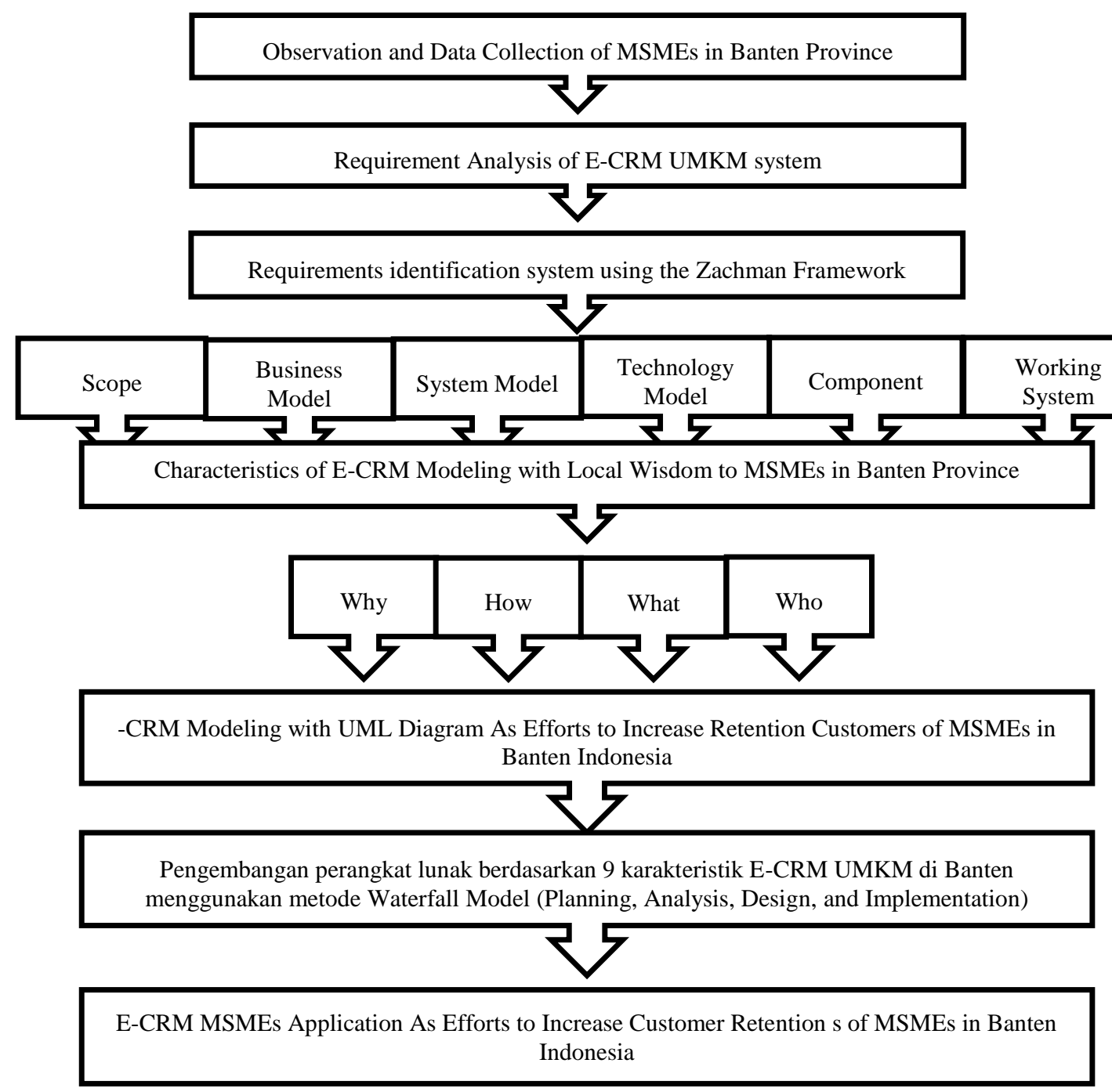

Figure 2: Process and Stage of E-CRM Implementation for MSMEs in Banten

\section{ANALYSIS AND RESULT}

Based on the results of observations and needs analysis that has been described in the previous stages, namely, identification of E-CRM needs for MSMEs in the Banten region by using the Zachman Framework which includes six perspectives (scope, business model, system model, technology model, component, and working system ) can produce a fairly complete and comprehensive analysis so that the E-CRM characteristics of MSMEs in the Banten region do not require features such as those in large companies but simple features tailored to the needs of MSMEs and loaded with local languages to present a userfriendly impression to MSME actors. The following are 9 characteristics [1] that must be applied to the E-CRM UMKM application in Banten province:

Table 2. Characteristic of E-CRM UMKM and Its Implementation in Banten Province

\begin{tabular}{|c|c|c|}
\hline No & Characteristic & Implementation in Application \\
\hline 1 & Local language & Using what MSME actors and customers use, namely, Indonesian \\
\hline 2 & Economical investment & The investation is only smartphone \\
\hline 3 & Easy to use and install & $\begin{array}{l}\text { Can be downloaded quickly through Google Play and can be used } \\
\text { immediately and easily }\end{array}$ \\
\hline 4 & Minimalis feature & $\begin{array}{l}\text { The features used by MSMEs are generally very minimalist, namely: } \\
\text { product management and customer management }\end{array}$ \\
\hline 5 & User friendly interface & $\begin{array}{l}\text { It is very easy to use as evidenced by the results of a limited pretest } \\
\text { and post test in using E-CRM UMKM application that has been carried } \\
\text { out for MSME actors, which is } 98 \% \text { can immediately understand the } \\
\text { use of E-CRM UMKM applications. [9] }\end{array}$ \\
\hline 6 & Android base interface & Can be used on all versions of the Android operating system \\
\hline
\end{tabular}




\begin{tabular}{|l|l|l|}
\hline $\mathbf{7}$ & Online or offline run application & $\begin{array}{l}\text { For some customer relationship management features can be used } \\
\text { offline for example: customer data, customer testimonial data, } \\
\text { customer complaint data, customer satisfaction data }\end{array}$ \\
\hline $\mathbf{8}$ & Simple database & $\begin{array}{l}\text { The database is relatively simple with a simple class diagram } \\
\text { consisting of } 20 \text { classes }\end{array}$ \\
\hline $\mathbf{9}$ & Use open source software & All of them use open source software to avoid dependency and costs \\
\hline
\end{tabular}

The following are the stages of developing E-CRM UMKM software in Banten province using the waterfall model and the results of each of these stages:

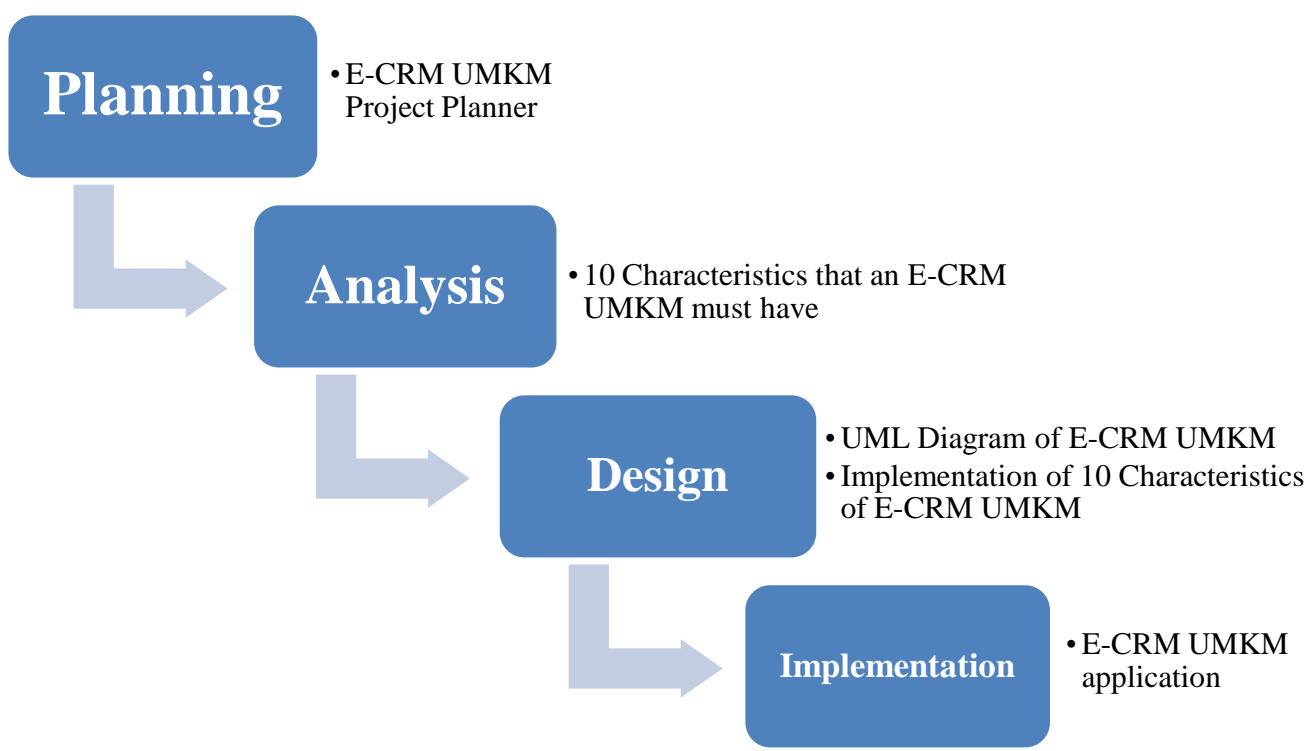

Figure 3. Development Stages of E-CRM UMKM

The following is the appearance of the E-CRM UMKM application developed using the waterfall method and built on nine characteristics of MSMEs in
Banten and the UML model resulting from the translation of four Zachman framework matrices:

\section{E-CRMUMKM}

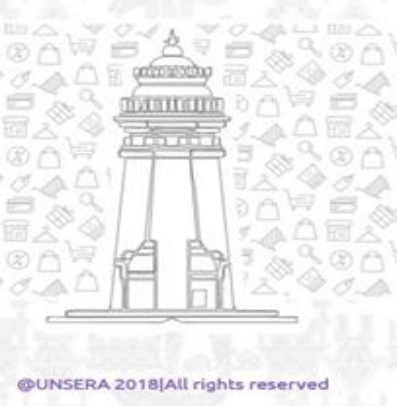

Figure 4: Dashboard of E-CRM UMKM with a touch of local wisdom in the form of the Banten Mosque Tower Sketch 


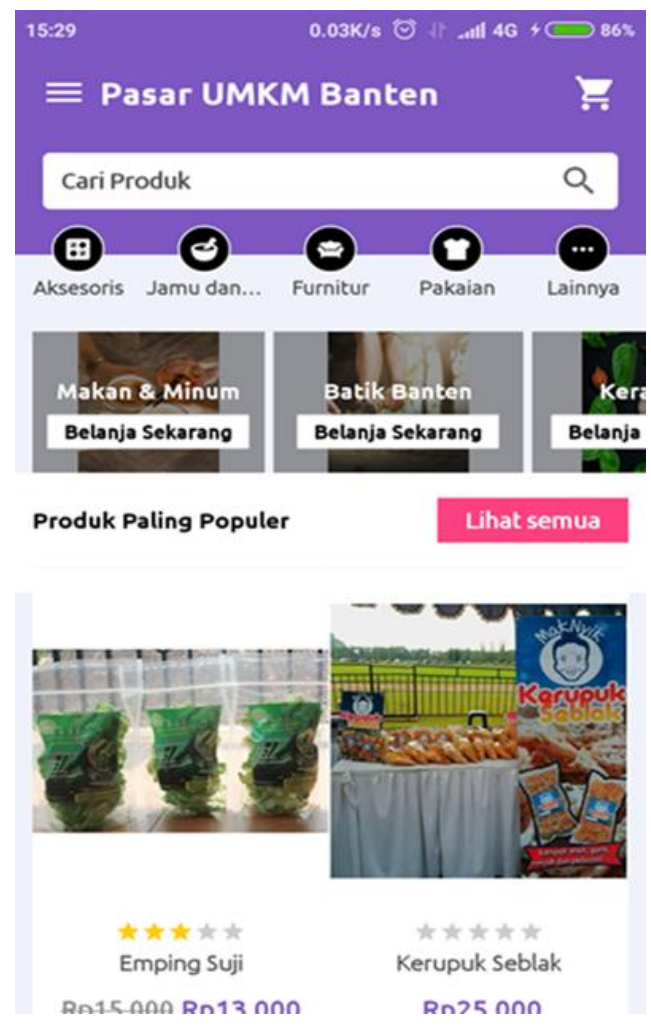

Figure 5: Searching Product Feature using Indonesian Language

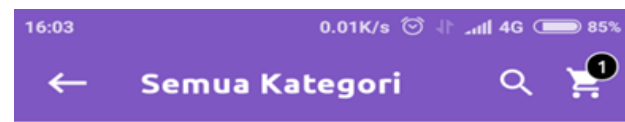

\begin{tabular}{ll}
\hline Aksesoris & $>$ \\
\hline Batik & $>$ \\
\hline Furnitur & $>$ \\
\hline Merajinan & $>$ \\
\hline Makanan dan Minuman & $>$ \\
\hline Pakaian & $>$ \\
\hline Perlengkapan Kantor & $>$ \\
\hline Sas & $>$
\end{tabular}

Figure 6: Searching Product based on Category with User Friendly 


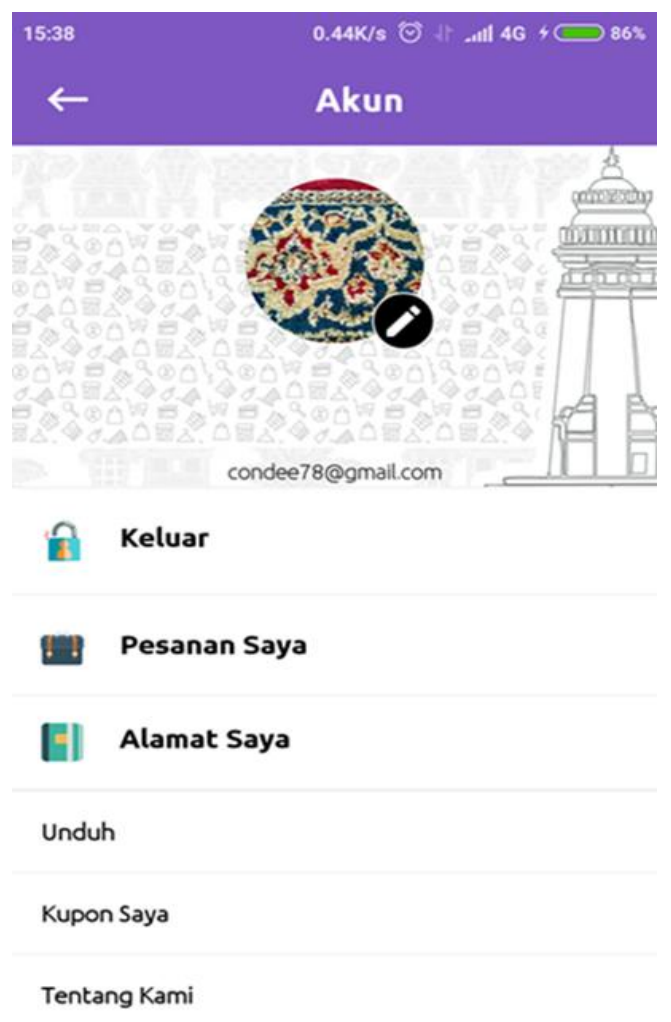

Figure 7: Login E-CRM UMKM

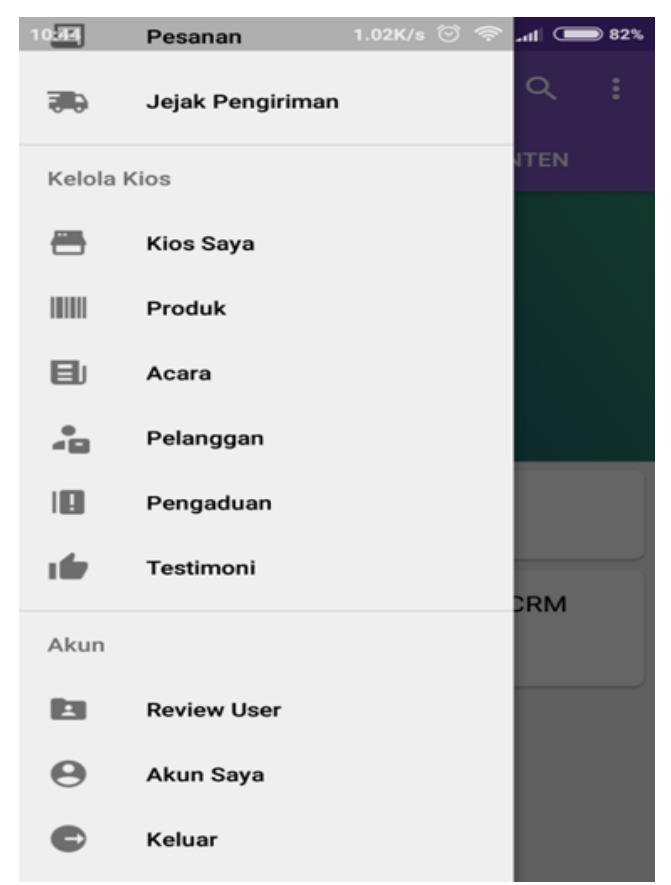

Figure 8: Minimalist features of E-CRM UMKM

\section{CONCLUSION}

From the discussion of the process, analysis and results described above, the following conclusions can be drawn:

a. Development of E-CRM software for MSMEs in the Banten region by referring to the 9 characteristics of the Banten MSMEs, namely, Indonesian language, economic investment, easy to use and install, minimalist features, user friendly interface, android base interface, online and offline run application, simple database, use open source software produces the MSMEs E-CRM application that presents a simple impression and has local wisdom, user friendly and easy to use by MSMEs actors in Banten in managing relationships with customers so the goal of building global marketing and increasing retention of MSME customers can be achieved. 
b. The development of E-CRM application in MSMEs in the Banten region through the stages of the waterfall model, namely planning, analysis, design, and implementation is quite effective and efficient so that it produces E-CRM UMKM in Banten province Indonesia.

\section{ACKNOWLEDGEMENT}

The authors would like to thank the Ministry of Research Technology and Higher Education of the Republic of Indonesia (KEMENRISTEKDIKTI) for the financial support.

\section{REFERENCES}

[1] Rosalina, Vidila., dkk. 2017, Electronic Customer Relationship Management (E-CRM) Modeling on Micro, Small \& Medium Enterprises (MSMEs) Banten, International Journal of Computer Applications (0975 8887) Volume 176, October 2017, New York, USA.

[2] Rosalina, Vidila, dkk. 2018, , Electronic Customer Relationship Management (E-CRM) Modeling As Effort to Increase Customer retentionon Micro, Small \& Medium Enterprises (MSMEs) Banten. ICComSET 2627 November 2018, Universitas Tasikmalaya, Jawa Barat, Indonesia

[3] Rifa'i, B. 2013. Efektivitas Pemberdayaan Micro Small and Medium Enterprises (UMKM) Krupuk Ikan dalam Program Pengembangan Labsite Pemberdayaan Masyarakat Desa Kedung Rejo Kecamatan Jabon Kabupaten Sidoarjo. Kebijakan dan Manajemen Publik, 130-136

[4] Sawitri,P., Wulandari, L., Simri, L.I.W. 2012. CRM untuk UKM, Konferensi Nasional Sistem Informasi 2012, STMIK - STIKOM Bali 23-25 Pebruari 2012

[5] Rosalina, Vidila. 2013, Pemodelan CRM Pada Perusahaan Petrokimia menggunakan Zachman Framework, Jurnal ELECTRANS ISSN 1412-3762, Volume 12 No 2 September 2013, UPI, Bandung.

[6] Danardatu, Aloysius Heru. 2003, Pengenalan Customer Relationship Management, Ilmu Komputer.Com
[7] Rosalina, Vidila, dkk. 2017. Sosialisasi Pemanfaatan ECRM untuk Meningkatkan Retensi Pelanggan UMKM . Jurnal Wikrama Parahita Vol 1 No1. November 2017

[8] Pressman, Roger S. 1997. Metode The Classic Life Cycle/Waterfall

[9] Rosalina Vidila. 2018. Pemanfaatan Aplikasi E-CRM Dalam Upaya Meningkatkan retensi Pelanggan UMKM, Seminar Nasional SEMBADHA 2018 pada tanggal 1718 November 2018. Di Sekolah Tinggi Akuntansi Negara (STAN) Bintaro Banten.

[10] Rosalina, Vidila, dkk. 2017. Model Electronic Customer Relationship Management (E-CRM) Menggunakan Adaptasi Bahasa Lokal Pada Usaha Mikro Kecil Menengah (UMKM) Banten, Prosiding SENASSET 2017 (Seminar Nasional Riset Terapan) ISBN 978-60273672-0-3 : 12, November 2017.

[11] Hashim, R. 2012. Adoption of enterprise information system (EIS) in Malaysian small and medium enterprises (SMEs). Business, Engineering and Industrial Applications (ISBEIA), 2012 IEEE Symposium: 425 430.

[12] Garcia, I., Pacheco, C., Martinez, A. 2012. Identifying Critical Success Factors for Adopting CRM in Small: A Framework for Small and Medium Enterprises. Software Engineering Research, Management and Applications 2012, Studies in Computational Intelligence Volume 430, 2012, pp 1-15

[13] Nugraha, A., Dewi, I.N., Novianto, S. 2013. Desain Pengembangan Aplikasi Electronic Customer Relationship Management dalam Mendukung Strategi Pemasaran dan Pengelolaan Pelanggan UMKM, Konferensi Nasional Informatika (KNIF) ITB 2013.

[14] Zachman, J.A., 2012, John Zachman's Concise Definition of the Enterprise Framework, http://www.zachman.com/aboutthe-zachman-framework. 